\title{
First report of Makinoella tosaensis OKADA (Chlorophyta, Chlorococcales, Oocystaceae) outside East Asia
}

\author{
František HindÁK \& Alica HindÁKovÁ
}

Institute of Botany, Slovak Academy of Sciences, Dúbravská cesta 9, SK-84523 Bratislava, Slovakia; e-mail: frantisek.hindak@savba.sk, alica.hindakova@savba.sk

\begin{abstract}
The morphology of Makinoella tosaensis Okada 1949, a chlorococcalean coenobial alga described from Japan and since then observed only in Korea, has been studied under the LM from field material and in laboratory cultures. Its collection from a small fountain in the campus park of the Slovak Academy of Sciences in Bratislava, Slovakia, is the first record outside East Asia. The morphology of coenobia and cells in this material is in agreement with published data of the species.
\end{abstract}

Key words: Chlorococcales, coenobial green algae, morphology, taxonomy, Slovakia

\section{Introduction}

In the algal flora of Slovakia project, special attention was paid to small artificial water bodies such as urban fountains. The diversity of algae was investigated in several fountains within the city limits of Bratislava (HINDÁK 1977, $1980 \mathrm{a}, \mathrm{b}$, 1984, 1988, 1990, 1996; HINDÁK \& HINDÁKOVÁ 1994, 1998; HindÁKOVÁ \& HiNdÁK 1998), including a small basin located at the campus of the Slovak Academy of Sciences (SAS) at Patrónka. From this locality a new tetrasporalean alga, Chlamydocapsa mucifera HindÁK 1980, was described, and an interesting green alga Oocystis nephrocytioides (HINDÁK 1977, 1980a) was observed which had originally been recorded by FоTT and ČADO from an artificial channel near Lake Ohrid, Macedonia, in 1966 (cf. KOMÁreK \& Fотт 1983).

In this contribution the morphology of cells and coenobia of the autosporic chlorococcal alga Makinoella tosaensis found in this specific man-made reservoir at the SAS campus is presented. As the only representative species of the genus, it was described from Japan by ОкаDA (1949) and studied by KamiYa (1956). The taxon was also reported by Yamigshi \& AkIYAMa in Photomicrographs of the Freshwater Algae (1984) and mentioned in several books on green algae but without adding any geographical data from other countries (e.g. Bourrelly 1966; KomÁreK
\& FoтT 1983). Outside of Japan (cf. http:// protist.i.hosei.ac.jp/PDB/Images/chlorophyta/ Makinoella/index.html), it was observed only in Korea (Hegewald et al. 1999). The strain SAG 28.97, isolated by Hegewald from Korea, is kept at the Algal Collection in Göttingen, Germany. The ultrastructure of this culture was investigated in detail by SchnepF \& Hegewald (2000). This strain was also used for molecular analyses and compared with some other representatives of the Oocystaceae (HEPPERLE et al. 2000).

\section{Material and methods}

Algal samples were collected from the water or periphyton growing on the concrete walls of a small basin with fountain on the campus of the Slovak Academy of Sciences in Bratislava, Western Slovakia, between July 2009 and January 2010 (Fig. 1). The basin is supplied by tap water, $\mathrm{pH}$ 7.2. Studies were performed on living material. Light microscope observations were carried out with a Leitz Diaplan microscope, and photomicrographs were taken with a Wild Photoautomat MPS45. Preserved material in formaldehyde is stored at the Institute of Botany SAS, Bratislava. Living material has been deposited as strain Hindák 2009/15 at the Culture Collection of Autotrophic Organisms (CCALA) in Třeboň, the Czech Republic. 


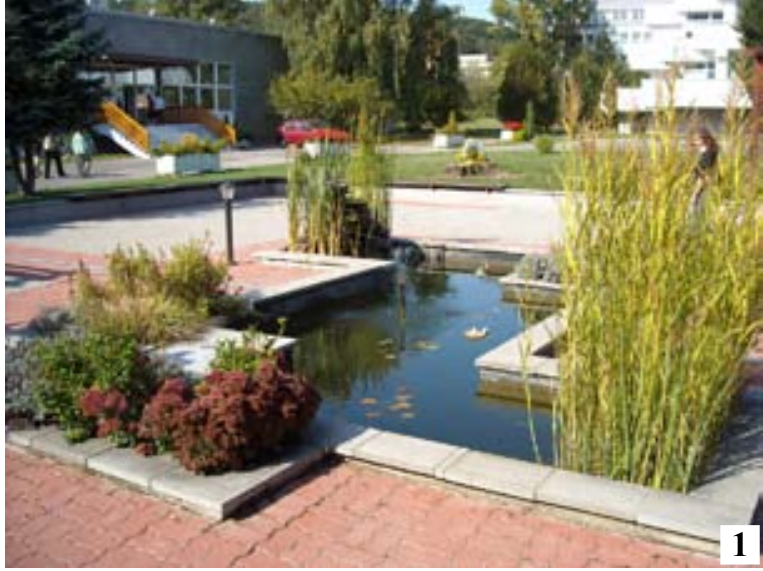

Fig. 1. Locality where Makinoella tosaensis Okada was collected: a basin with fountain in the campus area of the Slovak Academy of Sciences at Patrónka, Bratislava.

\section{Results and discussion}

\section{Makinoella tosaensis ОкаDA 1949 (Figs 2-5)}

Coenobia free, usually 4-8-16-celled, rarely $2-$ or $32-$ celled or cells solitary, embedded by wide, distinct, hyaline, slightly perpendicularly stratified mucilaginous envelopes, mostly clearly visible by radiating fibrils or radial arranged endogloeic rod-like bacteria. Four-celled coenobia square, with cells in one plane, touching each other subpolarly, inner cells in young stages and during autosporulation touching each other by their longitudinal sides. Subsequent cell division in 4-celled coenobia perpendicular to the plane of the coenobium, hence syncoenobia becoming rectangular, oval or irregular. Cells in adult 4-celled coenobia or later in syncoenobia arranged rhomboidally, with inner space. Old 16-celled syncoenobia usually disintegrating into solitary 4-celled coenobia or, very rarely, into solitary cells. Dimensions of 4-celled coenobia with mucilaginous envelopes $65-70 \times 50-65 \mu \mathrm{m}$, 16-celled coenobia 80-90 × 60-80 $\mu \mathrm{m}, 32-$ celled coenobia to $130 \times 105 \mu \mathrm{m}$.

Cells broad ellipsoidal to irregularly oval, slightly asymmetrical, 12-18-(23) × 8-12-(15) $\mu \mathrm{m}$, during autosporulation to $28 \times 18 \mu \mathrm{m}$. Cell walls thick, smooth, without incrustations or conspicuous polar thickenings. Chloroplasts 8-16 or more, bright green, parietal, discoid to slightly asteroid, each with a large central starchassociated pyrenoid.

Reproduction by autocoenobium with mostly 4, less frequently with 2 autospores.
Daughter cells remaining in the conspicuously enlarged mother cell wall for a long time, finally released by its gelatinisation.

Occurrence: colonies were found quite frequently and abundantly in the water or on the concrete walls of the basin among other cyanophytes and algae [we use here the classification system by HiNDÁK \& HindÁKOvÁ (1998), that has been adopted in the algal flora of Slovakia databank]. The colonies were accompanied by various species of cyanophytes (in the periphyton usually by Gloeocapsa sp., Leptolyngbya, Pseudanabaena catenata, Phormidium tenue, Calothrix stagnalis) or by different types of algal flagellates (Gymnodinium sp., Cryptomonas ovata, Rhodomonas rubra, Chlamydomonas debaryana, Euglena cf. caudata), chlorococcalalgae(Chlorellavulgaris, Coelastrum reticulatum, Coenocystis ovalis, Dictyosphaerium tetrachotomum, Didymocystis inconspicua, Golenkiniopsis solitaria, Kirchneriella aperta, $K$. obesa, Monoraphidium arcuatum, M. contortum, Oocystella solitaria, Pediastrum boryanum var. longicorne, Pseudodictyosphaerium minutum, Quadrigula sp., Scenedesmus abundans, $S$. acuminatus, $S$. armatus, $S$ communis, $S$. maximus, S. naegelii, S. obliquus, S. opoliensis, $S$. serratus, Siderocystopsis fusca); ulotrichacean algae (Elakatothrix spirochroma, Geminella interrupta, Koliella longiseta, Oedogonium sp., Cladophora glomerata) or zygnematophycean algae (Mongeotia spp., Closterium incurvum, Cosmarium leave).

Makinoella tosaensis was originally placed by its author in the family Oocystaceae, a classification that was followed by BOURRELLY (1966). On the basis of colony development KomÁREK \& FotT (1983) assigned it to the family Scenedesmaceae, but noted that according the original diagnosis the alga could also be classified in the Xanthophyceae, because of the absence of pyrenoids and presence of multiple chloroplasts. The ultrastructural studies performed by Hegewald et al. (1999) and Schnepf \& Hegewald (2000) proved the presence of many chloroplasts with a distinct starch envelope associated with the pyrenoids. The classification of Makinoella tosaensis in the Oocystaceae received full support also from the molecular analyses by HePperLe et al. (2000).

The 4-celled flat coenobia, with two cells forming an inner pair and two cells forming an outer pair, touching each other subpolarly, 

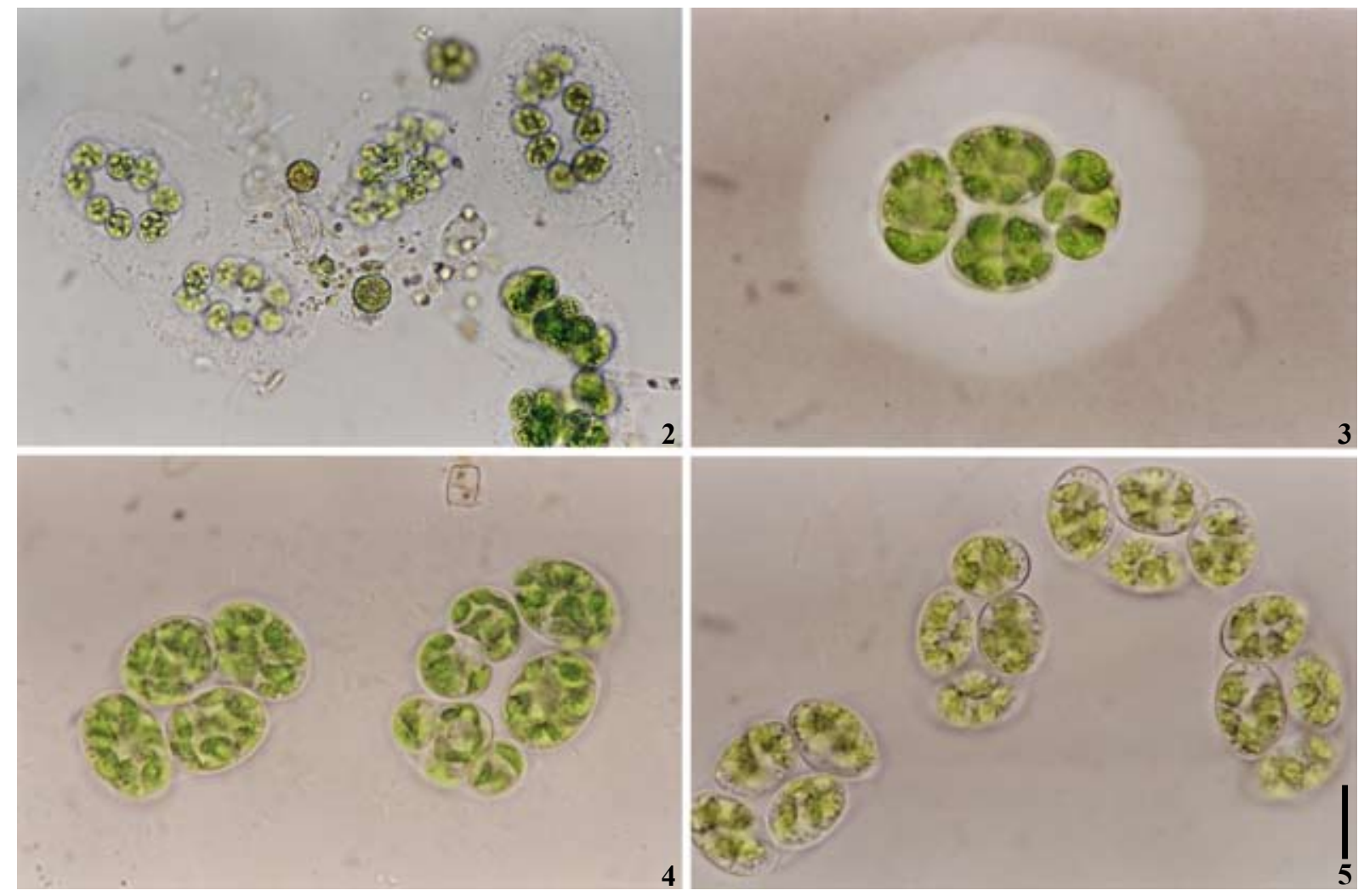

Figs 2-5. Coenobia of Makinoella tosaensis Okada from natural material: (2) coenobia at low magnification; $(3,4)$ autosporulation in 4-celled coenobia; (5) disintegration of a syncoenobium. Scale bar $20 \mu \mathrm{m}$.

resemble colonies of the genus Tetrachlorella KorSHIKOV (KorSHIKOV 1953; KOMÁreK \& FotT 1983; HINDÁK 1984). However, the internal space of coenobia in M. tosaensis is rectangular, rhomboidal or asymmetrical, with the exception of young stages of cells or during autosporulation when inner cells are connected or touched by their longer sides.

Makinoella tosaensis shares the feature of the numerous discoid chloroplasts, each with a pyrenoid, with some representatives of the genus Oocystis A. Braun, namely the group of O. solitaria WitTr. in Wittr. et NoRdst. (cf. KomÁreK \& FotT 1983; HindÁK 1984). However, contrary to $O$. solitaria, cells in $M$. tosaensis are never lemon shaped, because of the absence of conspicuous polar thickenings. Only rarely very slight polar thickenings were seen in a culture, strain HINDÁK 2009/15.

The occurrence of the species in small water basins seems to be typical. In Japan $M$. tosaensis has been recorded from several places, in similar small water bodies, mostly in park ponds, and in Korea from a small campus pond in the Sookmyung Women's University in Seoul (Hegewald et al. 1999). Until recently we could consider M. tosaensis to be an endemic species for East Asia. Its finding in Central Europe shows that this species has probably a cosmopolitan distribution, occurring in temperate zone (Japan, Korea, Slovakia). Our material does not differ significantly from published descriptions of the species. Under laboratory conditions, the alga grows well both in liquid and on agar BBM media. We were successful in isolating several strains, from which one strain, HindÁK 2009/15, was selected to be deposited at the Culture Collection of Autotrophic Organisms (CCALA) in Třeboň, the Czech Republic.

\section{Acknowledgements}

The authors are obliged to Dr. H. Sluiman, Edinburgh, for valuable comments and correcting the English. This study is a part of APVV 0566-07 and VEGA projects Nos 2/7069/27 and 2/0130/10 supported by the Slovak Academy of Sciences.

\section{References}

Bourrelly, P. (1966): Les algues d'eau douce. Initiation à la systématique. Tome I: Les algues vertes. 512 pp., Ed. N. Boubée, Paris. 
Hegewald, E., Schnepf, E. \& Jeon, S.L. (1999): Report on Makinoella tosaensis Okada (Chlorophyta, Oocystaceae), a new species to Korea. - Algae 14: 87-90.

Hepperle, D., Hegewald, E. \& Krienitz, L. (2000): Phylogenetic position of the Oocystaceae (Chlorophyta). - J. Phycol. 36: 590-595.

HindÁk, F. (1977): Studies on the chlorococcal algae (Chlorophycea). - Biologické Práce 23/4. - 192 pp., Veda, Bratislava.

Hindák, F. (1980a): Studies on the chlorococcal algae (Chlorophyceae). II. - Biologické práce 26/6. 196 pp., Veda, Bratislava.

HindÁk, F. (1980b): Three new species of green algae (Chlorophyceae). - Preslia 52: 289-298.

Hindék, F. (1984): Studies on the chlorococcal algae (Chlorophyceae). III. - Biologické práce 30/1. -310 pp., Veda, Bratislava.

HindÁk, F. (1988): Studies on the chlorococcal algae (Chlorophyceae). IV. - Biologické práce 34/1-2. - 264 pp., Veda, VSAV, Bratislava.

HindÁk, F. (1990): Studies on the chlorococcal algae (Chlorophyceae). V. - Biologické Práce 36. 228 pp., Veda, Bratislava.

HiNDÁk, F. (1996): Kl'úč na určovanie nerozkonárených vláknitých zelených rias (Ulotrichineae, Ulotrichales, Chlorophyceae) [Key to unbranched filamentous green algae (Ulotrichineae, Ulotrichales, Chlorophyceae)]. - Bull. Slov. Bot. Spoločn., Bratislava, Supl. 1: $1-77$.

HindÁk, F. \& Hindáková, A. (1994): Some interesting observations on desmids (Conjugatophyceae). Biologia 49: 525-533.

HindÁk, F. \& HindÁková, A. (1998): Zoznam siníc a rias Slovenska [Checklist of cyanophytes/ cyanobacteria and algae of Slovakia], p. 12 - 100. In: MARHOLD K. \& HindÁK F. (eds), Zoznam nižších a vyšších rastlín Slovenska [Checklist of non-vascular and vascular plants of Slovakia]. - Veda, Bratislava.

HindÁkovÁ, A. \& HindÁK, F. (1998): Green algae of five city fountains in Bratislava (Slovakia). Biologia 53: 481-493.

KamiYA, T. (1956): A report on the reproduction of Makinoella tosaensis Okada. - J. Jap. Bot. 31: 257-261.

KomÁreK, J. \& FotT, B. (1983): Chlorophyceae (Grünalgen), Ordnung: Chlorococcales. - In: Huber-Pestalozzi,G.(ed.):DieBinnnengewässer 16/7. - 1044 pp., E. Schweizerbart'sche Verlagsbuchhandlung, Stuttgart.

Korshikov, O.A. (1953): Pidklas Protokokovi (Protococcinae). - Vizn. Prisnovod. Vodorostei Ukrainskoi RSR, Kiev, 5: 1-436.

OKADA, Y. (1949): Makinoella tosaensis, a new genus of he Oocystaceae. - J. Japan. Bot. 24: 166168.

Schnepf, E. \& Hegewald, E. (2000): The ultrastructure of Makinoella tosaensis Okada (Chlorophyta, Oocystaceae). - Algological Studies 97: 79-91.

YAMAgShi, T. \& AkiYAmA, M. (1984): Photomicrographs of the Freshwater Algae 1: 58.

http://protist.i.hosei.ac.jp/PDB/Images/chlorophyta/ Makinoella/index.html; Photomicrographs of the Freshwater Algae, 1984.

(C) Czech Phycological Society

Received December 23, 2009

Accepted January 15, 2010 